\title{
Gross Anatomical and Histomorphological Studies on Liver with Ramification of Portal Vein and Hepatic Artery in Ghungroo Pig
}

\author{
Palash Biswas ${ }^{1 *}$, Sanjay Ray ${ }^{1}$, Partha Das ${ }^{1}$, Sagun Saren $^{1}$, Arkaprabha Shee ${ }^{1}$, \\ Aniruddha Banerjee ${ }^{2}$ and Md. Mofijul Islam ${ }^{1}$ \\ ${ }^{1}$ Department of Veterinary Anatomy and Histology, Faculty of Veterinary and Animal \\ Sciences, WBUAFS, Kolkata-37, India \\ ${ }^{2}$ Department of Veterinary Pathology, Faculty of Veterinary and Animal Sciences, WBUAFS, \\ Kolkata-37, India \\ *Corresponding author
}

\begin{abstract}
A B S T R A C T
The present study was conducted on Ghungroo pig to investigate gross anatomical and histomorphological structure with ramification of portal vein and hepatic artery in liver. For the present investigation, ten livers were collected from adult, apparently healthy,

\section{Keywords}

Ghungroo pig, Liver, Histomorphology, Hepatic artery, Portal vein

\section{Article Info}

Accepted:

20 May 2018

Available Online:

10 June 2018 freshly slaughtered Ghungroo pigs. Immediately after collection, gross anatomical observation was done. Out of ten livers, five were used for identification of portal vein and hepatic artery by RTV Silicone cast method and another five for the histological preparation. Histomorphological study was done by H \&E, PAS and Masson's Trichrome staining method. From the gross observation, it was found that the liver of pig was situated within the intra-thoracic part of the abdominal cavity. A small caudate lobe was found along with the four principal lobes. In the present study, it was revealed that hepatic artery before entering into the porta divided into right and left major branches which supplied to the lobes of liver. The portal vein entered the hilus of the liver between the hepatic artery dorsally and bile duct ventrally. Histological section of pig liver revealed that the outer most surface of parenchyma was covered with a fibrous capsule. The most predominate fibre of the capsule was collagen. The liver lobules were polyhedral to hexagonal in shape. The lobule was composed of hexagonal hepatic tissue measuring on an average $1.89 \mathrm{~mm}$ in length and approximately $1.23 \mathrm{~mm}$ in short diameter.
\end{abstract}

\section{Introduction}

The modern breeds of pig evolved from different crossings between the two original types and the present day domestic pig, Susdomesticus is the result of thousands of years of evolution through gradual domestication. In recent years the pig has been increasingly used as an experimental animal, especially in the field of liver transplantation (Peacock \& Terblanche, 1967; Hunt, 1967; Hobbs et al., 1968; Calne et al., 1969) owing to its similarity to man in having no hepatic vein sphincters, in being omnivorous, and in having similar blood biochemistry (Peacock and Terblanche, 1967). Ghungroo pig is an indigenous and potential strain first reported from North Bengal, West Bengal. Ghungroo 
are mostly black in colour with typical Bulldogs face appearances however, docile in nature. There are few literatures are available on the gross anatomy and histology of Ghungroo pig liver. The present study was conducted with the objective of determining gross anatomical and histomorphological structure with ramification of portal vein and hepatic artery in liver of the Ghungroo pig.

\section{Materials and Methods}

\section{Place of the study}

The present study was carried out at the Department of Veterinary Anatomy and Histology, West Bengal University of Animal and Fishery Sciences, Kolkata from February 2016 to January 2017.

\section{Source of Samples}

To undertake the present investigations, ten livers were collected from adult, apparently healthy, freshly slaughtered Ghungroo pigs from local slaughter house.

\section{Gross anatomical and morphological studies}

Immediately after collection, gross anatomical observation was done by naked eye. The gross appearance, positional significance and colour of the liver were noted. Digital camera was used to record the location of the organ.

\section{Study of hepatic artery and portal vein} ramification

Five numbers of livers were used for identification of portal vein and hepatic artery by RTV Silicone cast method. RTV Silicone (Anabond) was procured from the local market and diluted with chloroform. The semiliquid silicone pest was injected in portal vein and hepatic artery respectively after flushing the both with normal saline. After injecting the liver samples were kept for natural decay. The silicone cast respective structures were collected and washed with diluted $\mathrm{HCl}$.

\section{Histological Studies}

For the histological slide preparation five numbers of livers from different pigs were collected in $10 \%$ neutral buffered formalin solution. All the tissues were subjected to the standard procedures of processing before proceeding for sectioning. All the sections were taken at $5 \mu \mathrm{m}$ thickness and consecutively stained with Haematoxylin and Eosin, Masson's Trichrome and PAS staining methods as described by Suvarna et al., (2012).

Microscopy was done by using Leica Qwin Image Analyser software in Lecia DM 2000 Microscope. The images were taken from the stained sections. All metric parameters were calculated by observing standard statistical protocol and were expressed as mean \pm standard error.

\section{Results and Discussion}

\section{Gross anatomical and morphological studies}

The liver of Ghungroo pig was relatively large and irregular in shape. It was thick in the center but the circumference was thin. The liver was light to dark brownish red in colour (Figs. 1, 2).

The average weight and volume of the livers of Ghungroo pigs were $1.54 \pm 0.21 \mathrm{~kg}$ and $1.425 \pm 0.192$ lit. Respectively (Table 1). This was in accordance with findings of Nickel et al., (1967), Vishwanath (1967), Sisson (1975), Ommer and Harshan (1995) and Carvalho-desouza et al., (2005) in case of pig. 
The liver of Ghungroo pigwas situated within the intra-thoracic part of the abdominal cavity. The major portion of liver was situated right of the median plane. The parietal surface of the liver was laid against of the concavity of diaphragm. The cranial most part of the liver was extended within the cranial most part of the diaphragm, directly with the sternum and touched the 5th intercostal space. The caudal extremity of liver was extended along the 8th and 9th ribs on the left and reached caudally along the convex line on the right, which was at the proximal end of the 13th and 14th ribs, passed to the costocondral junction of the 10th and 11th ribs. From there the liver was placed transversely to the ventral midline. Both the left lobes and right medial lobe were in contact with abdominal wall ventrally. The parietal surface was against the concavity of the diaphragm. The visceral surface was mostly in contact with the stomach. The jejunum was in contact with part of the right medial and right lateral lobes (Figs.1, 2.). Similar observation was documented by Nickel et al., (1967) and Sisson (1975) in pig. There was no renal impression, because of the liver of pig did not make contact with the right kidney. This was in accordance with findings of Carvalho-de-souza et al., (2005).

The coronary ligament in Ghungroo pigs was connected the liver to the diaphragm, extended from the short left triangular ligament to the righttriangular ligament passing around the ventral surface of the caudal venecava (Fig.3). The round ligament was situated within the notch for the round ligament. Its medial course continued toward the umbilicus. The falciform ligament was thick represented by a narrow peritoneal band over the diaphragmatic surface of the liver (Fig.2). These results are in agreement with the description of liver of pig by Nickel et al., (1967).

The liver of Ghungroopig was divided by three deep interlober fissures into four principal lobes: right medial (right central), left medial (left central), right lateral and left lateral. Out of the four lobes left lateral lobe was considerably the largest one. A small caudate lobe was found along with the four principal lobes. Caudate lobe was situated on the dorsal part of the right lateral lobe (Fig.1, 2).

The caudate lobe was clearly marked off by a fissure and partially subdivided by a secondary fissure. The caudate process was projected towards the right side dorsally. Similar results were also reported by the previous reports of Nickel et al., (1967), Vishwanath (1967), Sisson (1975).

\section{Study ofportal vein ramification}

The portal vein entered the hilus of the liver between the hepatic artery dorsally and the bile duct ventrally (Fig.4). It immediately divided into; 1, Ramus dorsalis dexter2. Ramus ventralisdexterand then proceeded to the left as 3. Ramus sinister. From the present observation it was revealed that the intrahepatic distribution of the portal vein in the liver of Ghungroopig was divided into two major portal segments; right and left.

The right portal segment included the caudate, right lateral and right medial lobes (Fig.4, 5). The left portal segment consisted of the left lateral, left medial lobes (Fig.4, 5). Similar observation was mentioned by Osman et al., (2008). The result published by Büchler et al., (2004) was partially agreed with the present findings in Ghungroopig.

\section{Study of hepatic arteryramification}

In its extra hepatic course, close to the liver porta the hepatic artery gave of a various number of branches which entered the liver and accompanied the branches of portal vein (Fig. 5, 6). 
Fig.1 Photograph showing gross liver (diaphragmatic surface) of Ghungroo pig with right lateral lobe (RL), right medial lobe (RM), left medial lobe (LM), left lateral lobe (LL), incision of round ligament (IRD) and diaphragm (D)

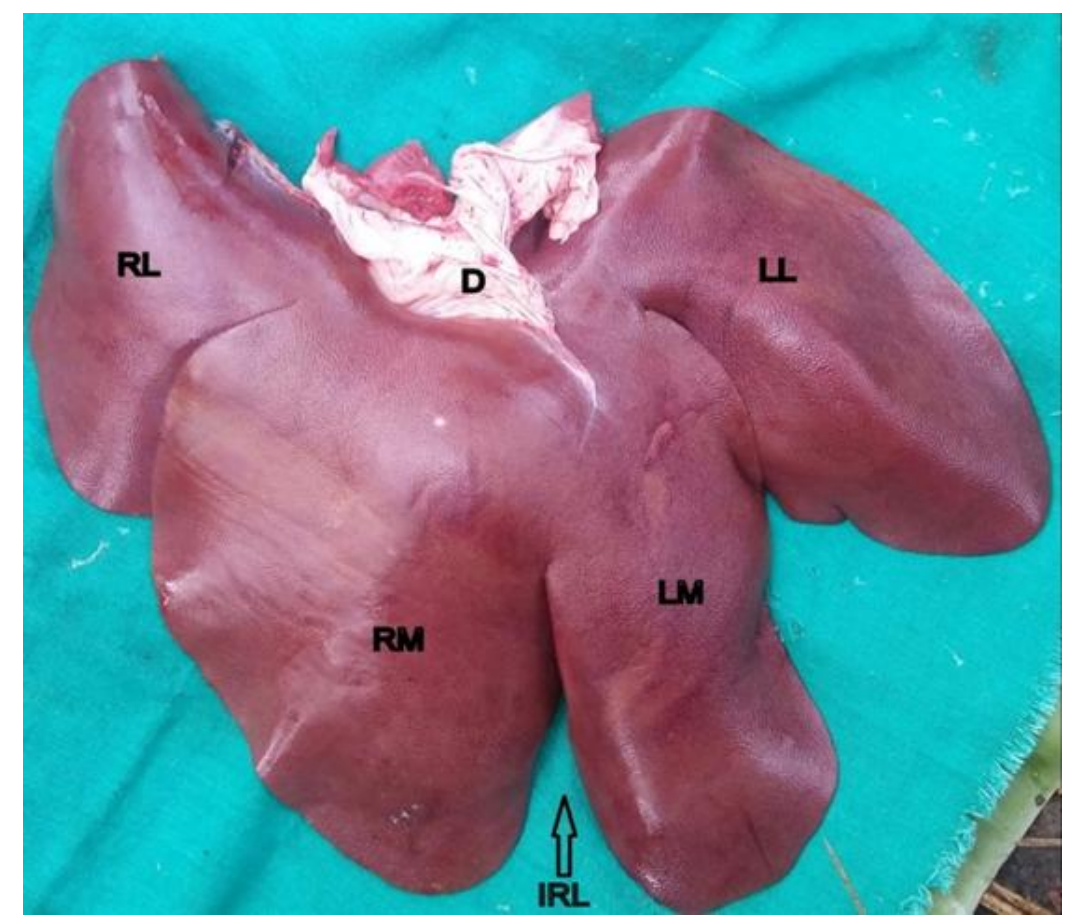

Fig.2 Photograph showing gross liver (visceral surface) of Ghungroo pig with caudate lobe (CL), right lateral lobe $(\mathrm{RL})$, right medial lobe $(\mathrm{RM})$, left medial lobe (LM), left lateral lobe (LL), gallbladder $(\mathrm{G})$ and cystic duct $(\mathrm{C})$

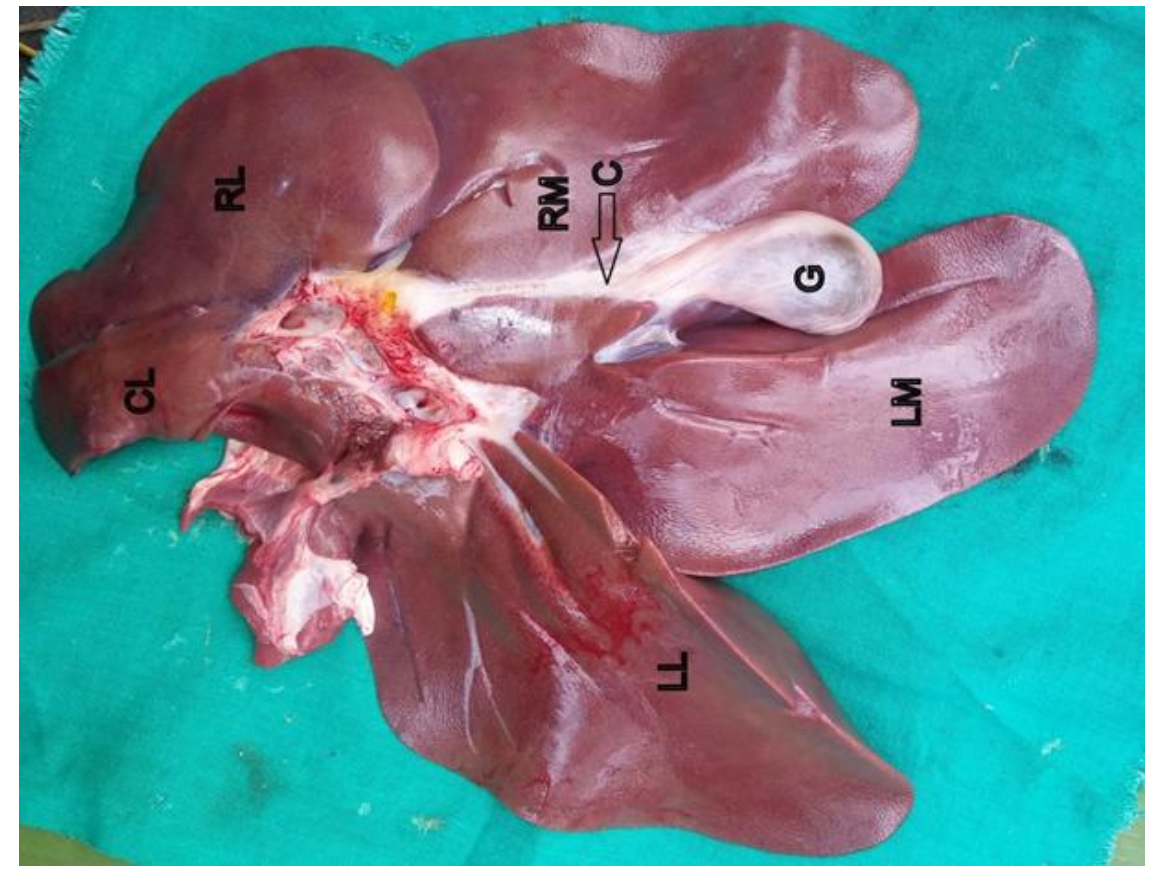


Fig.3 Photograph of liver of Ghungroo pig showing opening of the venacava $(\mathrm{O})$ coronary ligament $(\mathrm{F})$

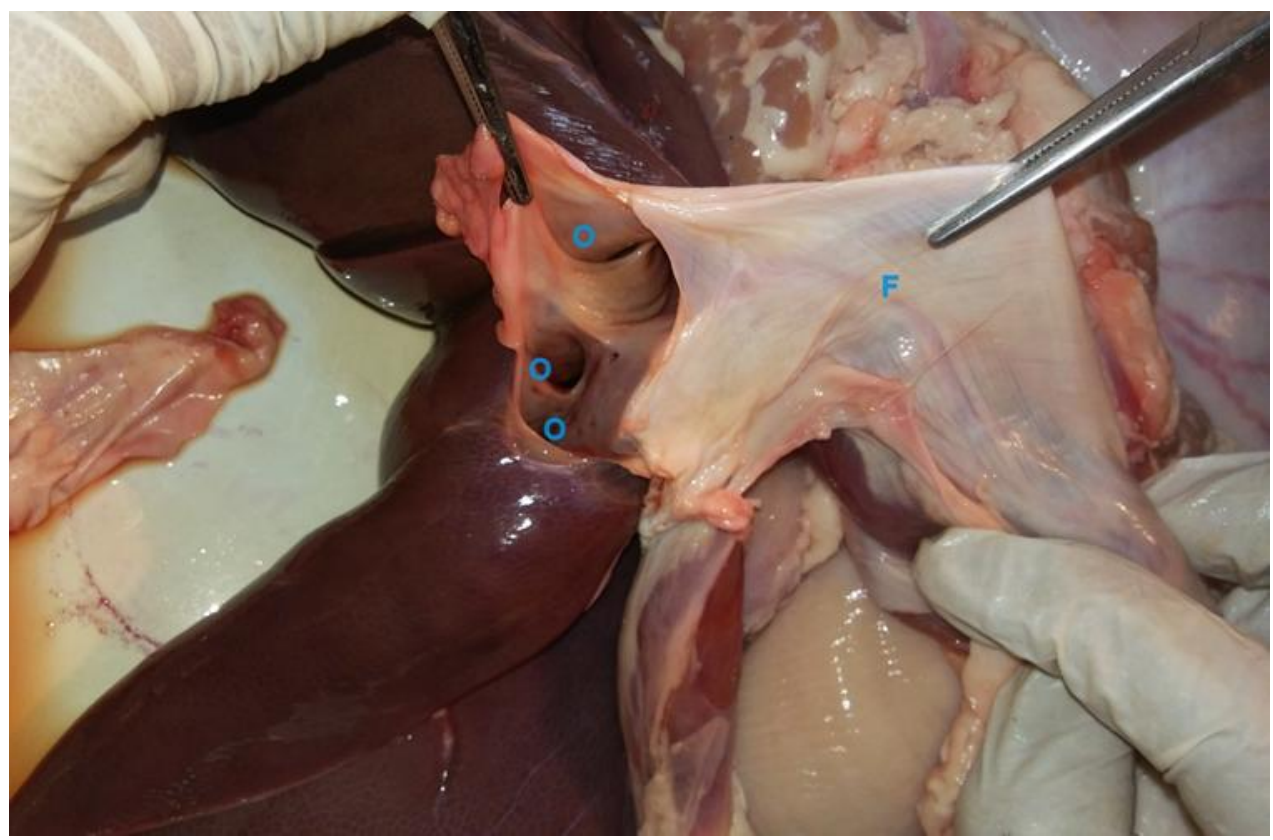

Fig.4 Photograph showing the parenchymal distribution of the portal vein (RTV Silicone injected specimen)

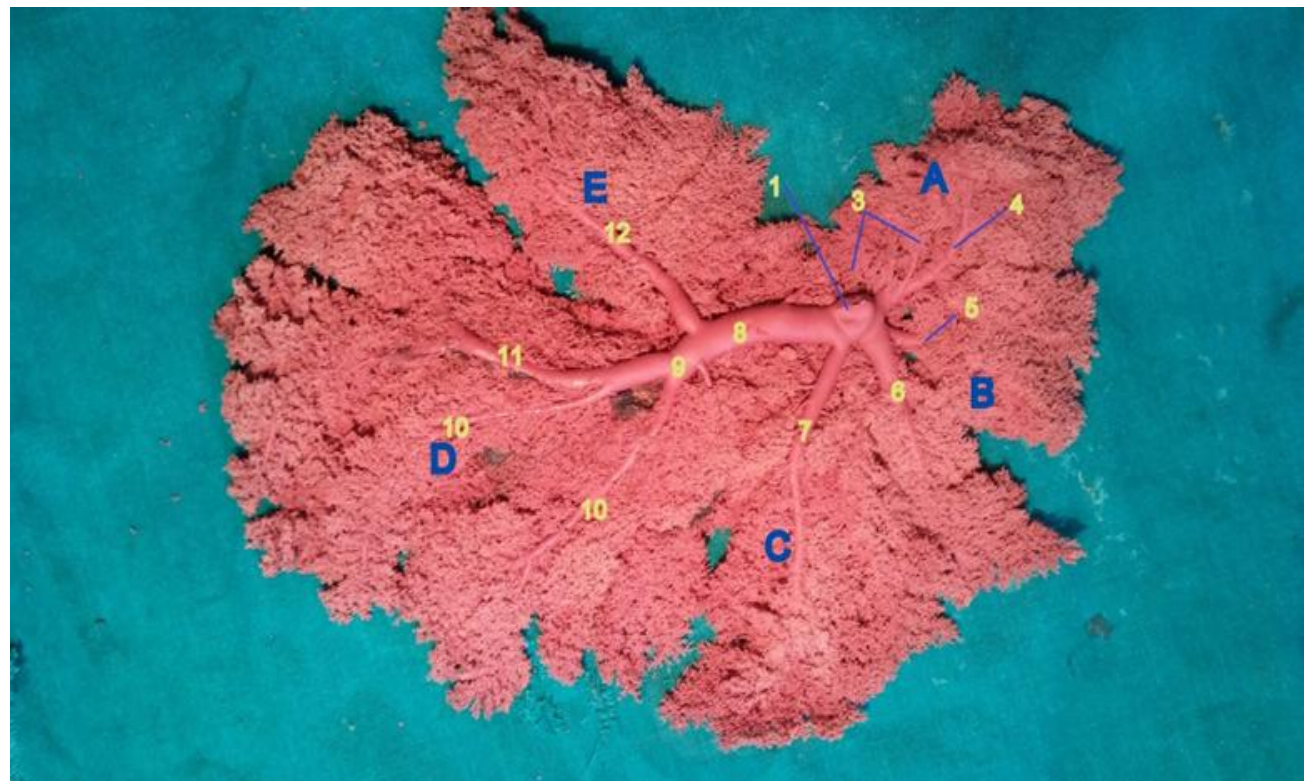

A-Processuscaudatus, B-Lobus hepatis dexter lateralis, C-Lobus hepatis dexter medialis, D-Lobus hepatis sinister medialis, F-Lobus hepatis sinister lateralis.

1. Venae portae, 2. R. dorsalis dexter, 3. Rr. processuscaudatus, 4. R. dorsalis lobi lateralis dextri, 5. R. intermedius lobi later-alisdextri, 6. R. ventralislobi lateralis dextri, 7. R. ventralisdexter, 8. R. sinister (pars transversa), 9.R. sinister (pars umbili-calis), 10. Rr. lobi medialis sinistri, 11. R. ventralislobi lateralis sinistri, 12. R. dorsalis lobi lateralis sinistri. 
Fig.5 Photograph showing distribution of portal vein and hepatic artery in different lobes of liver of Ghungroo pig. (HA=hepatic artery; PV= portal vein).PV1 and HA1: caudate lobe branch; PV2 and HA2: right lateral branch; PV3 and HA3: right medial branch, PV4 and HA4: left medial branch and PV5 and HA5: left lateral branch

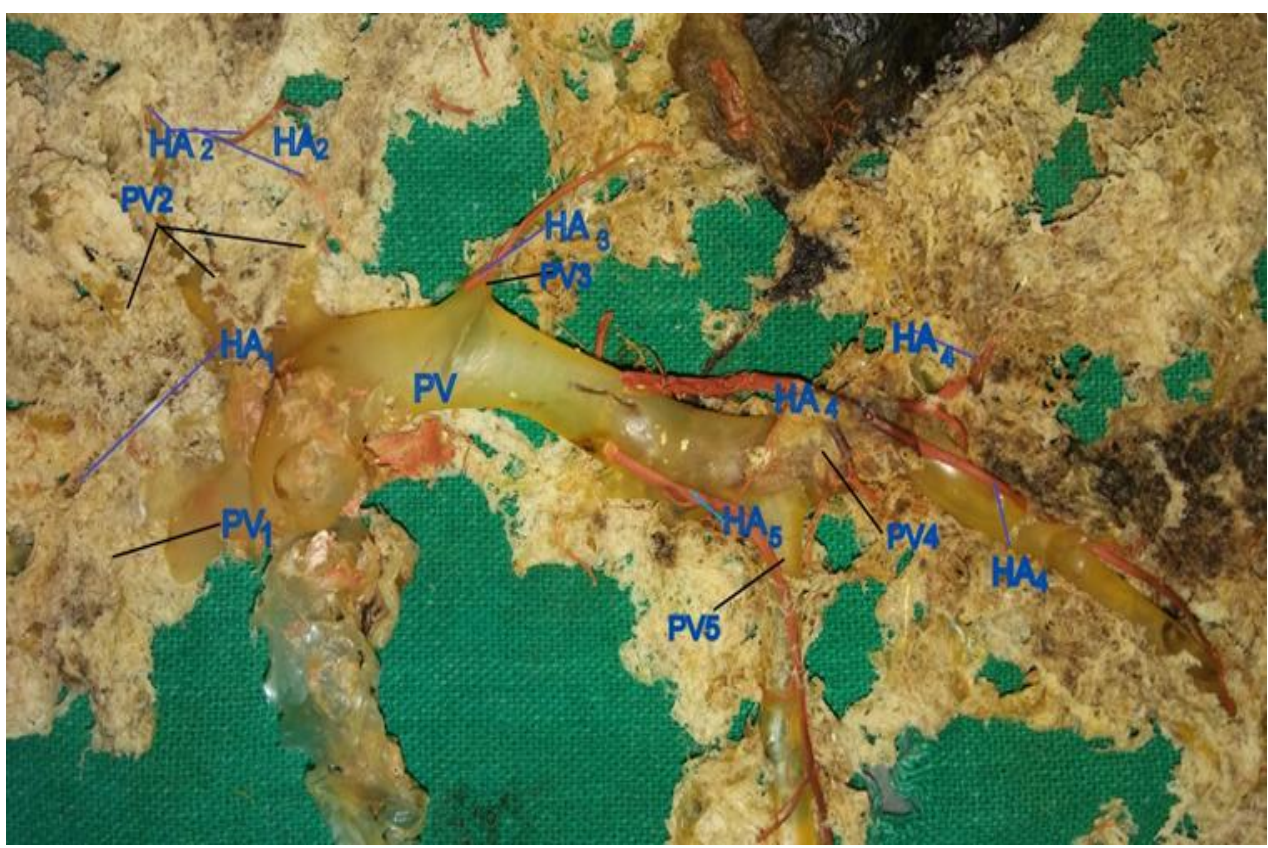

Fig.6 Photograph showing the hepatic artery $(\mathrm{H})$, major branches of hepatic artery ('a' and ' $b$ '), 1 and 2 branches of ' $a$ " and 2 and 3 branches of ' $b$ '. $G=$ gallbladder, and LM= left medial lobe

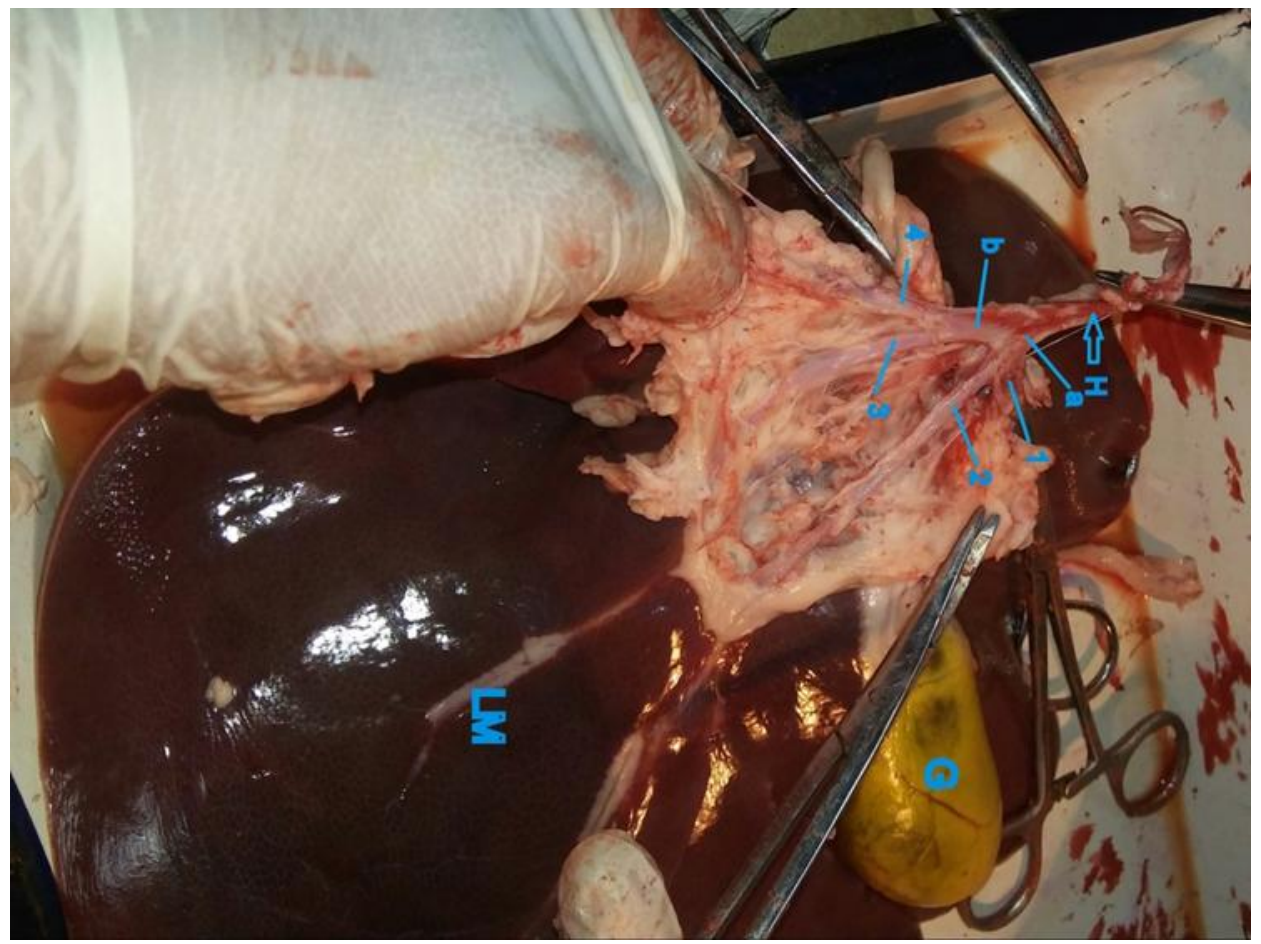


Fig.7 Photomicrograph showing central vein (CV), connective tissue septa (CTS), bile duct (BD), hepatic artery (HA), portal vein(PV), portal vein, branch(PVB), and portal tract (PT).

$\mathrm{H} \& \mathrm{E}, \mathrm{X} 4$

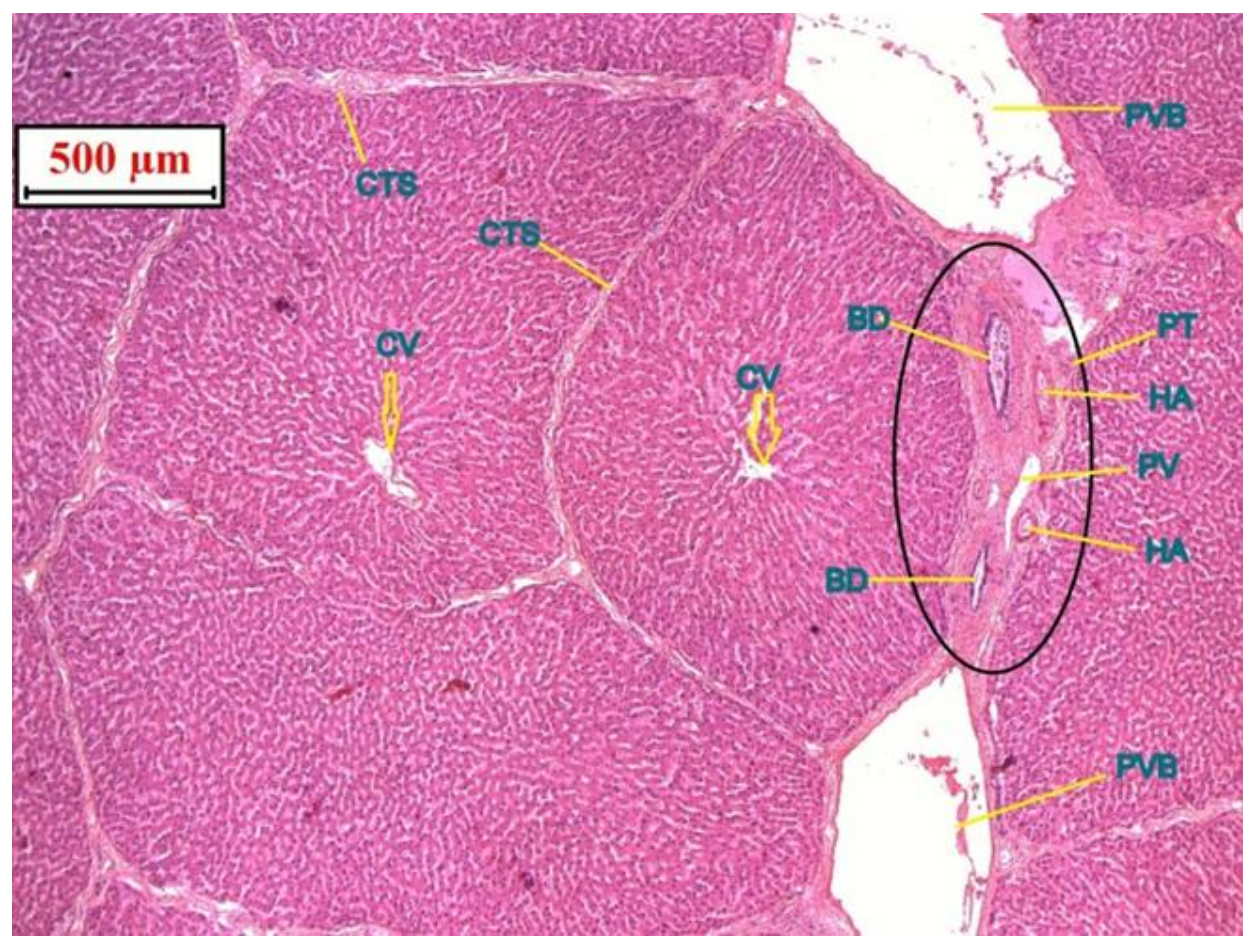

Fig.8 Photomicrograph of liver of pig showing Glisson's capsule $(G)$ and connective tissue septa (CTS). H\&E, X10

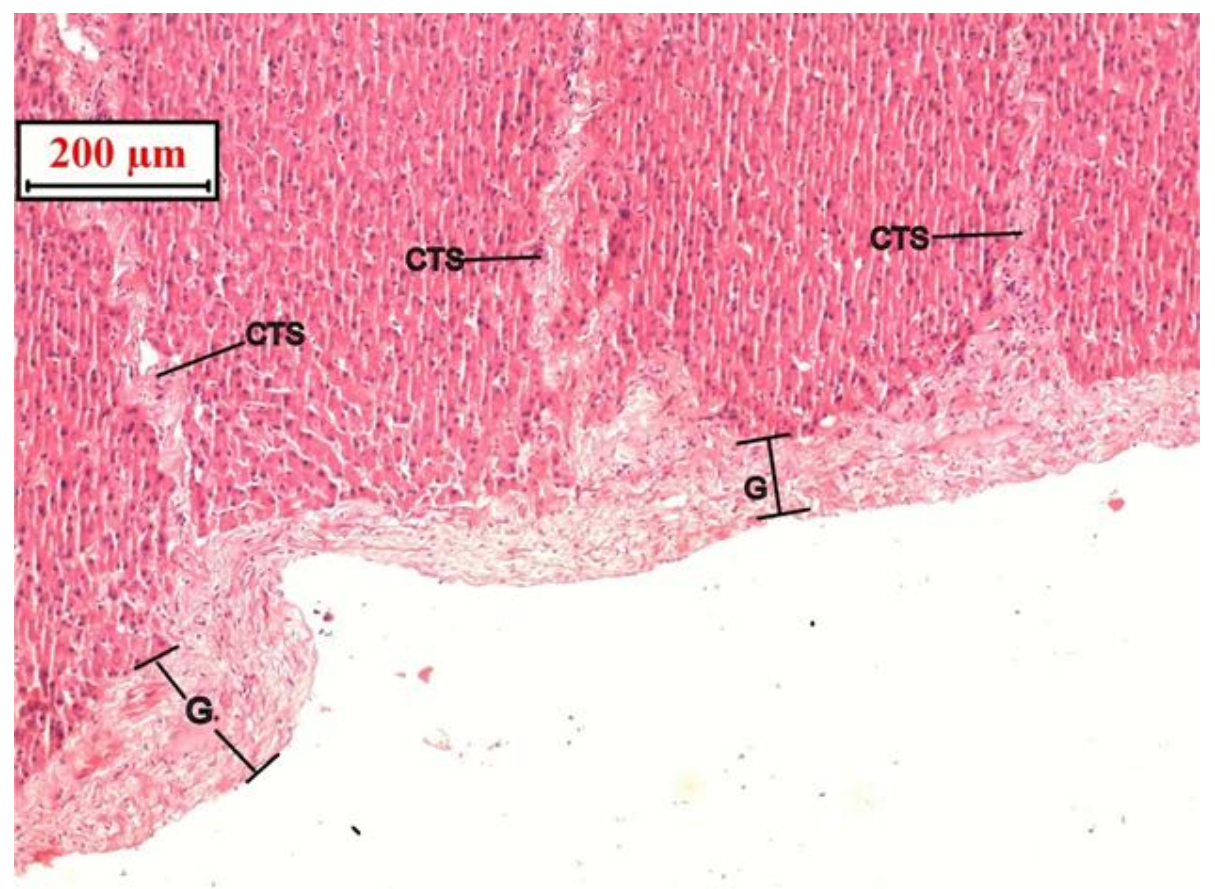


Fig.9 Photomicrograph of liver showing central vein (CV), connective tissue septa (CTS) and collagen fiber (C). MT, X10

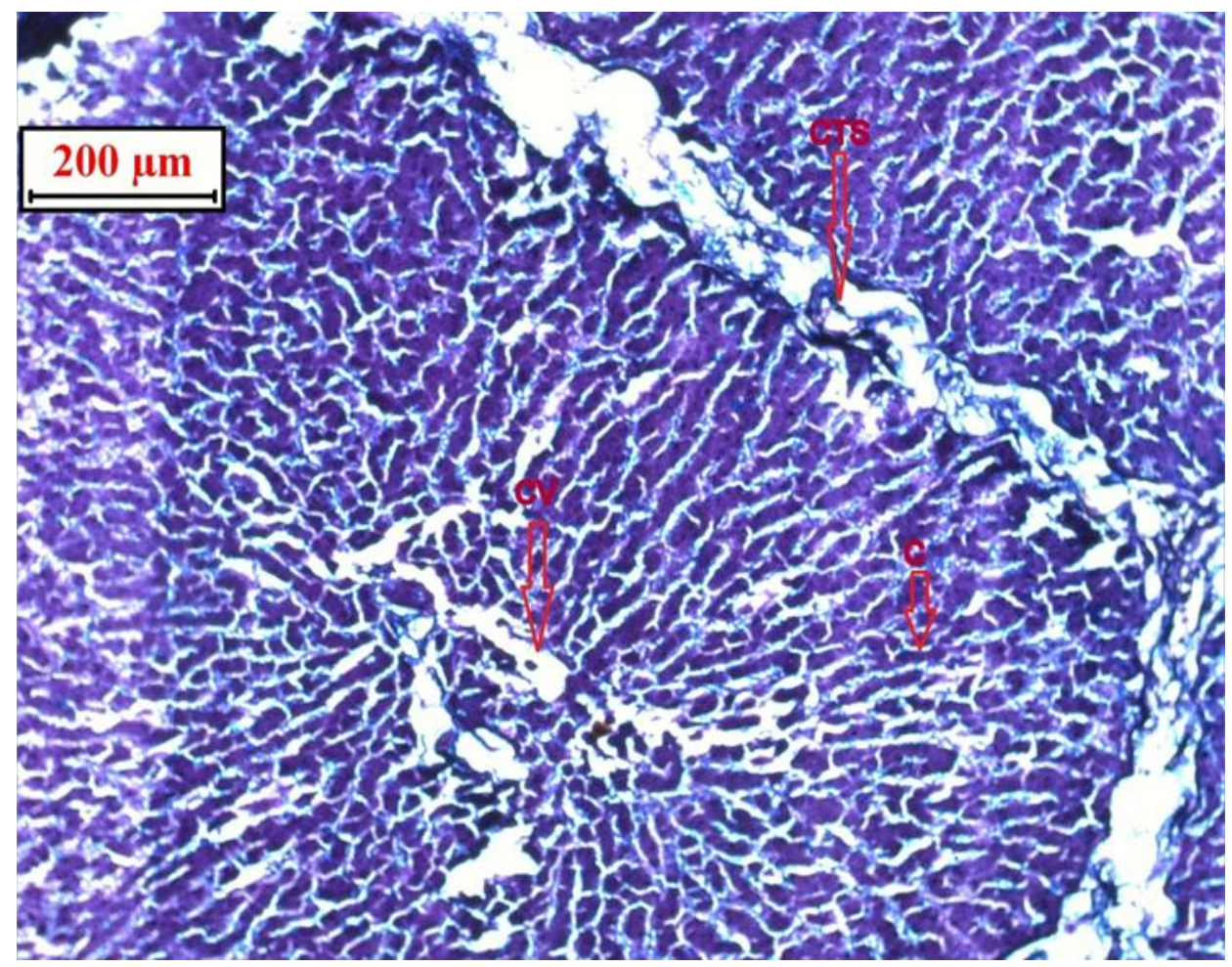

Fig.10 Photomicrograph of liver showing central vein (CV) and connective tissue septa (CTS). PAS, X4.

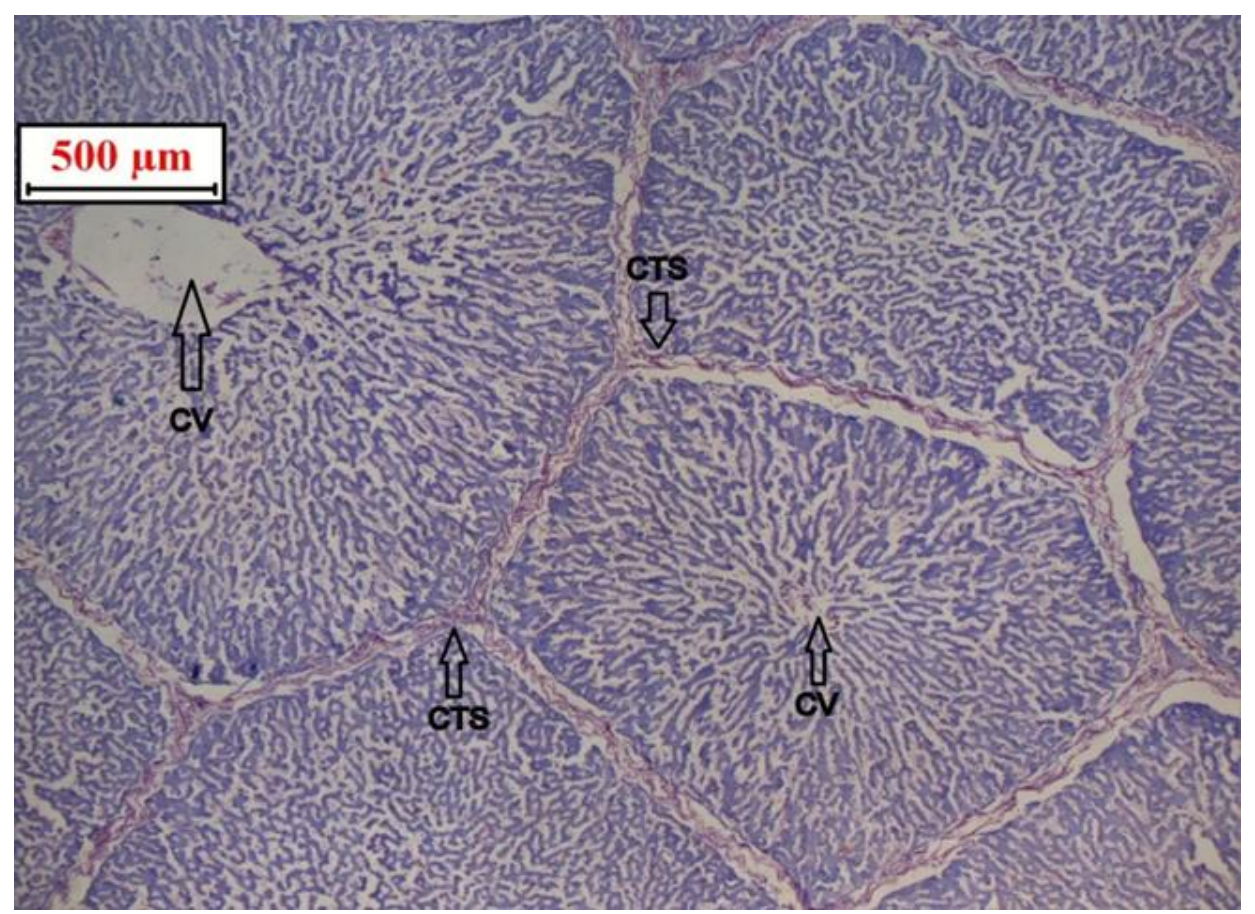


Table.1 Mean \pm SE of relative weight and volume of liver of Ghungroo pig

\begin{tabular}{|l|c|c|}
\hline \multicolumn{1}{|c|}{ Parameter } & Average & Range \\
\hline Weight(kg) & $1.54 \pm 0.21$ & $1.2-1.8$ \\
\hline Volume (lit.) & $1.425 \pm 0.192$ & $1.1-1.7$ \\
\hline
\end{tabular}

Table.2 Mean \pm SE measurements (m.m.) of long and short diameter in length of hepatic lobules

\begin{tabular}{|l|}
\multicolumn{1}{c}{ Parameter } \\
\hline Long length of hepatic lobules(m.m.) \\
\hline Short diameter of hepatic lobules(m.m.)
\end{tabular}

\section{Histological Studies}

Histological section of Ghungroopig revealed that the outer most surface of parenchyma was covered with a fibrous capsule which resembled the Glisson's capsule of the other mammalian species (Fig.7, 8). The most predominate fiber of the capsule was collagen (Fig.9, 10).

The fibrous coat (Glisson's capsule) adhered to the serous coat externally and the gland substances internally. Some of the lobules appeared as typically hexagonal and rests were polygonal in outline in a single histological section. Few muscle fibres were found in the capsule but not into the interlober connective tissue. The interlober connective tissues also supported the vascular, bile duct and lymphoid vessels. Similar observation was cited by Vidyarthi (1968).

Hepatic lobule of liver was polygonal and usually appeared hexagonal in cross section with a central vein at centre with portal triad peripherally. The parenchymal or hepatic cells were arranged in series of branching and anastomosing perforated plates or laminae to form a spong work or labyrinth. In Ghungroo pig liver much of the lumen of the hepatic sinusoid was occupied by large cytoplasmic processes originating from Kupffer cells. Similar results have been reported by Flaks (1971).

\begin{tabular}{|c|c|}
\hline A verage & Range \\
\hline $1.89 \pm 0.137$ & $1.63-2.10$ \\
\hline $1.23 \pm 0.176$ & $1.02-1.50$ \\
\hline
\end{tabular}

The anatomical or morphological unit of liver was formed around the central vein. The lobule was composed of hexagonal hepatic tissue measuring about approximately $1.89 \pm 0.137 \mathrm{~mm}$ in long and approximately $1.23 \pm 0.176 \mathrm{~mm}$ in short diameter in length. (Table 2). Hepatic cord at sinusoid area were directed to the central vein. Portal canal were found approximately three of the six angle of the lobule. The hepatic cord was one cell thick. However, Vidyarthi (1968) and Lal (1980) documented the average diameter of liver lobule was $1 \mathrm{~mm}$. Dellmann and Brown (2006) and Ghosh (2015) described that the average long and short diameter of the lobule of pig was $2 \mathrm{~mm}$ and $1 \mathrm{~mm}$. Fawcett (1994) stated that the lobule was about $0.7 \mathrm{~mm}$ in diameter and $2 \mathrm{~mm}$ long on in average.

The liver of Ghungroo pig was situated within the intra-thoracic part of the abdominal cavity. The liver was divided into four principal lobes and a small caudate lobe which was along with the four principal lobes. As the liver did not make contact with the right kidney, there was no renal impression. There were six ligaments in the liver of Ghungroopig which connected the liver with other organs. In the present investigation, it was revealed that hepatic artery before entering the porta divided into right and left major branches which supplied to the lobes of liver. The portal vein entered the hilus of the liver between the hepatic artery dorsally and 
bile duct ventrally. Histomrphological study suggested that the outer most surface of parenchyma was covered with a fibrous capsule which resembled the Glisson's capsule of the other mammalian species. The liver lobules were polyhedral to hexagonal in shape. The lobule was composed of hexagonal hepatic tissue measuring on an average $1.89 \mathrm{~mm}$ in length and approximately $1.23 \mathrm{~mm}$ in short diameter.

\section{Acknowledgement}

The authors are very much grateful to ViceChancellor, West Bengal University of Animal and Fishery Sciences; Dean, Faculty of Veterinary \& Animal Sciences, WBUAFS. Head of the Department of Veterinary Anatomy and Histology, WBUAFS, Kolkata, India for providing necessary facilities.

\section{References}

Büchler, J.A.B., Prates, J.C. and Fragoso Neto, R.A. (2004). Ramification of the hepatic artery in swine (Sus scrofadomestica). International Journal of Morphology, 22(4), 263-266.

Calne, R. Y., White, H. J. O., Binns, R. M., Herbertson, B. M., Millard, P. R., Pena, J., Salaman, J. R., Samuel, J. R. and Davis, D. R. (1969). Immunosuppressive effects of the orthotopically transplanted porcine liver. Transplantation Proceedings, 1, 321-324.

Carvalho-de-souza, B., Babinski, M.A. and Abidu-figueiredo, M. (2005). Morphology and Topographical Aspect of the Wild Boar Liver. Revista Cientifica Eletronica De Medicina Veterinaria.

Dellmann, H.D. and Brown, E.M. (2006). Text Book of Veterinary Histology. $6^{\text {th }}$ edn. Lea and Febiger, Philadelphia. pp. 201-206.
Fawcette, D.W. (1994). In: A textbook of Histology. $12^{\text {th }}$ edn., Chapman and Hall publishers. New York London. pp.677.

Flaks, B.O.J.A.N. (1971). Observations on the fine structure of the normal porcine liver. Journal of anatomy, 108(3), 563.

Ghosh, R.K. (2015). In: Primary Veterinary Anatomy. $\quad 6^{\text {th }}$ edn. Current Books International, Kolkata. pp. 239.

Hobbs, K. E. F., Hunt, A. C., Palmer, D. B., Badrick, F. E., Morris, A. M., Mitra, S. K., Peacock, J. H., Immelman, E. J. and Riddell, A. G. (1968). Hypothermic low flow liver perfusion as a means of porcine hepatic storage for six hours. British Journal of Surgery, 55, 696-703.

Hunt, A. C. (1967). Pathology of liver transplantation in the pig. In: The Liver (Proc. 19th Symp. Colston Res. Soc.), edited by A. E. Read, Butterworth, Colston, London. 19, 337-349.

Lal, S.S. (1980). In: Text Book of Practical Zoology. $4^{\text {th }}$ edn., Rastogi Publications. Shivaji Road, Meerut. pp. 198.

Nickel, R; Schummer, A. and Seiferle, E. (1967). In The viscera of the Domestic Mammals. Vol. 2, $2^{\text {nd }}$ edn., Verlag Paul Parey, Berlin, Hamburg, Berlin, Germany. pp. 145-146.

Ommer, P.A. and Harshan, K.R. (1995). Revised reprint (1977). In: Applied Anatomy of the Domestic Animals. $1^{\text {st }}$ edn., Jaypee Brothers. pp. 50-51.

Osman, F.A., Wally, Y.R., El-Nady, F.A. and Rezk, H.M., (2008). Gross anatomical studies on the portal vein, hepatic artery and bile duct in the liver of the pig. Journal of Veterinary Anatomy, 1(1), 59-72.

Peacock, J. H. and Terblanche, J. (1967). Orthotopic homotransplantation of the liver in the pig. In: The Liver (Proc. 19th Symp. Colston Res. Soc.), edited by A. E. Read. Butterworth, Colston, London. Pap. 19, 333-336. 
Sisson, S. (1975). Porcine Digestive System. In: Getty, R. (ed). Sission and Grossman's, The Anatomy of the Domestic Animals. Vol. 2, $5^{\text {th }}$ edn., W.B. Saunders Company, Philadelphia, London. pp. 1280-1281.

Suvarna, K. S., Layton, C., and Bancroft, J. D. (2012). Bancroft's Theory and
Practice of Histological Techniques EBook. Elsevier Health Sciences.

Vidyarthi, R.D. (1968). In: Text Book of Zoology. $11^{\text {th }}$ edn., Agrasia publishers, Daresi, Agra. pp. 503.

Vishwanath M.S. (1967). In: A textbook of Zoology. Vol. 2, S. Chand \& Co., Madras. pp. 513.

\section{How to cite this article:}

Palash Biswas, Sanjay Ray, Partha Das, Sagun Saren, Arkaprabha Shee, Aniruddha Banerjee and Md. Mofijul Islam. 2018. Gross Anatomical and Histomorphological Studies on Liver with Ramification of Portal Vein and Hepatic Artery in Ghungroo Pig. Int.J.Curr.Microbiol.App.Sci. 7(06): 2955-2965. doi: https://doi.org/10.20546/ijcmas.2018.706.348 